\title{
Visual Activity in the Telencephalon of the Painted Turtle, Chrysemys picta
}

\author{
ANDREW H. BASS*, MICHAEL L. ANDRY and R. GLENN NORTHCUTT \\ Division of Biological Sciences, University of Michigan, Ann Arbor, MI 48109 (U.S.A.)
}

(Accepted August 23rd, 1982)

Key words: turtles - telencephalon - vision - multiple unit activity

\begin{abstract}
Multiple unit activity in response to visual stimulation was recorded in the following telencephalic areas of the painted turtle: lateral and medial divisions of the dorsal cortex, lateral and medial divisions of the dorsal ventricular ridge, and the striatum. The data confirm anatomical evidence for ascending visual input to the dorsal cortex, the lateral dorsal ventricular ridge and the striatum. The identification of a new visual zone in a medial division of the dorsal ventricular ridge suggests that turtles, and perhaps other reptiles, possess at least 3 visual pallial areas.
\end{abstract}

\section{INTRODUCTION}

The dorsal ventricular ridge is a subcortical telencephalic structure in reptiles and birds. Although earlier neuroanatomists compared the dorsal ventricular ridge to the subpallium (i.e. corpus striatum) of mammals, recent documentation of ascending visual, auditory and somesthetic input to separate divisions of the dorsal ventricular ridge suggests homology with the pallium (i.e. sensory isocortices) ${ }^{8,30}$. This comparison excludes primary visual cortex, which is homologized to the dorsal cortex and Wulst of reptiles and birds, respectively.

In reptiles, the dorsal cortex and the dorsal ventricular ridge are two pallial targets of ascending visual pathways $^{30}$. Physiological ${ }^{26,33}$ and anatomical ${ }^{17,18}$ studies in turtles reveal a cortical visual zone that receives input via a retino-thalamic (thalamofugal) pathway. Although a retinotecto-thalamic (tectofugal) pathway terminates in a lateral division of the dorsal ventricular ridge and, possibly, in the striatum $^{3,4,17,18}$, there is no physiological evidence of the number or extent of subcortical visual areas. Nor is it known whether turtles and other reptiles are characterized by more than two visual pallial zones, as are some birds ${ }^{6}$ and mammals ${ }^{20}$.

In this paper, we document visually responsive zones in the telencephalon of the painted turtle, Chrysemys picta, and present evidence for two visual zones in the dorsal ventricular ridge, in addition to those in the dorsal cortex and striatum. A preliminary report appeared earlier ${ }^{5}$.

\section{MATERIALS AND METHODS}

\section{Animals}

Fifteen painted turtles, Chrysemys picta, ranging from 200 to $696 \mathrm{~g}$ weight and 12.0 to $19.5 \mathrm{~cm}$ carapace length, were housed in a large trough containing cement blocks and water. A heat lamp operating on a $12 \mathrm{~h}$ on/off cycle was placed above the trough, and the animals were maintained on a diet of smelt and fruit.

\section{Surgery}

All turtles were anesthetized prior to surgery with intraperitoneal injections of sodium pentobarbitol $(25-30 \mathrm{mg} / \mathrm{kg})$, and additional injections $(5 \mathrm{mg} / \mathrm{kg})$ were given as needed to maintain a suitable level of anesthetization. Animals were held in a smallanimal stereotaxic device during all surgical and electrophysiological procedures. A small cork placed between the lower jaw and the mouthpiece of the stereotaxic frame allowed unimpeded respira-

\footnotetext{
* Present address : Section of Neurobiology and Behavior, Seeley G. Mudd Building, Cornell University, Ithaca, NY 14853, U.S.A.
} 
tion. The dorsal surface of the telencephalon was exposed by removing the overlying parietal bone and reflecting the meninges. In 4 animals, the dorsal surface of the optic tectum was also exposed. Mineral oil was placed over the brain to prevent dessication, and eyelids were retracted by fine suture thread attached to the stereotaxic frame. Rectal temperatures ranged from 21 to $25{ }^{\circ} \mathrm{C}$ during experiments.

\section{Electrophysiological recordings}

Electrophysiological methods were adapted from previous studies of reptilian visual systems ${ }^{1,2}$. All experiments were conducted in a darkened room and lasted approximately $12 \mathrm{~h}$.

Electrical activity was monitored by glass insulated bipolar platinum-iridium electrodes with $75 \mu \mathrm{m}$ tips. The tip of each pair was cut at an oblique angle, so that the tips of the electrode wires were separated by $100-150 \mu \mathrm{m}$. Monopolar recordings were obtained by grounding one electrode of a pair. The left hindlimb of the turtle was grounded to the stereotaxic frame.

Recorded activity was amplified and displayed on a storage oscilloscope, and selected tracks were photographed with a C5A Tektronix camera.

\section{Stimulation}

Visual stimulation was provided by light emitting (525 $\mu \mathrm{m}$ wavelength) diodes (LEDs) mounted on insulated copper wire attached to the stereotaxic frame. Each LED was placed perpendicular to the eye surface at a distance of $4 \mathrm{~mm}$ and activated by a specially designed pulsing unit.

At each recording depth, the LED was turned off for $20 \mathrm{~s}$, then activated for $2 \mathrm{~s}$ every $4 \mathrm{~s}$. This procedure was followed for two reasons: (a) evoked potential activity or multiple unit responses to light onset ( $\mathrm{ON}$ response) were often absent if light stimulation was not withheld for at least $20 \mathrm{~s}$; (b) evoked potential or multiple unit responses to light offset (OFF response) were often absent when light stimulation was delivered at a rate less than one flash per $4 \mathrm{~s}$.

Every recording site was tested with contralateral, ipsilateral, and bilateral stimulation, and both $\mathrm{ON}$ and OFF responses were monitored after long (20 s) and short ( $4 \mathrm{~s})$ dark intervals.

\section{Histology}

At the termination of each experiment, the turtle was administered an overdose of sodium pentobarbitol and perfused transcardially with $0.7 \%$ saline followed by AFA (90 $\mathrm{cc}$ of $80 \%$ ethanol, $5 \mathrm{cc}$ formalin, $5 \mathrm{cc}$ glacial acetic acid). The brain was removed from the skull, placed in fixative for at least 1 week, and then embedded in paraffin. All material was serially sectioned at $15 \mu \mathrm{m}$, and representative sections were photographed to illustrate telencephalic recording sites.

\section{Localization of recording sites}

Due to their large size, it was possible to reconstruct the pathway of most electrode penetrations (Figs. 3, 5B); the tracks were marked by tissue disruption and blood accumulation. The drag of the electrodes against the pia dimpled the surface of the dorsal cortex, which confounded absolute depth measurements but did not obscure the topography of recording tracks in histological material (Figs. 3, 5B). In many cases, electrolytic lesions were made at the deepest point in the track by passing $50 \mu \mathrm{A}$ of anodal current for $10 \mathrm{~s}$, as additional verification of recording sites (Figs. 4A, B, 5A).

\section{RESULTS}

\section{Evoked potential and multiple unit activity}

Initially, changes in evoked potential activity were monitored to locate multiple unit activity. Along many tracks, evoked potential components reversed polarity (typically negative-positive inversions with monopolar recordings) as the electrode went deeper; these reversals were usually associated with multiple unit activity (Fig. 3). Many tracks, however, yielded a different response pattern: (a) multiple units when little or no evoked potential activity was seen; or (b) a large evoked response that did not invert, despite the presence of multiple units. We therefore concentrated on multiple unit activity because we believed it more precisely reflected the locations of units that respond to visual stimuli.

\section{Visual regions}

A total of 118 electrode tracks were made throughout the telencephalon. Multiple units that responded to visual stimuli were encountered along 


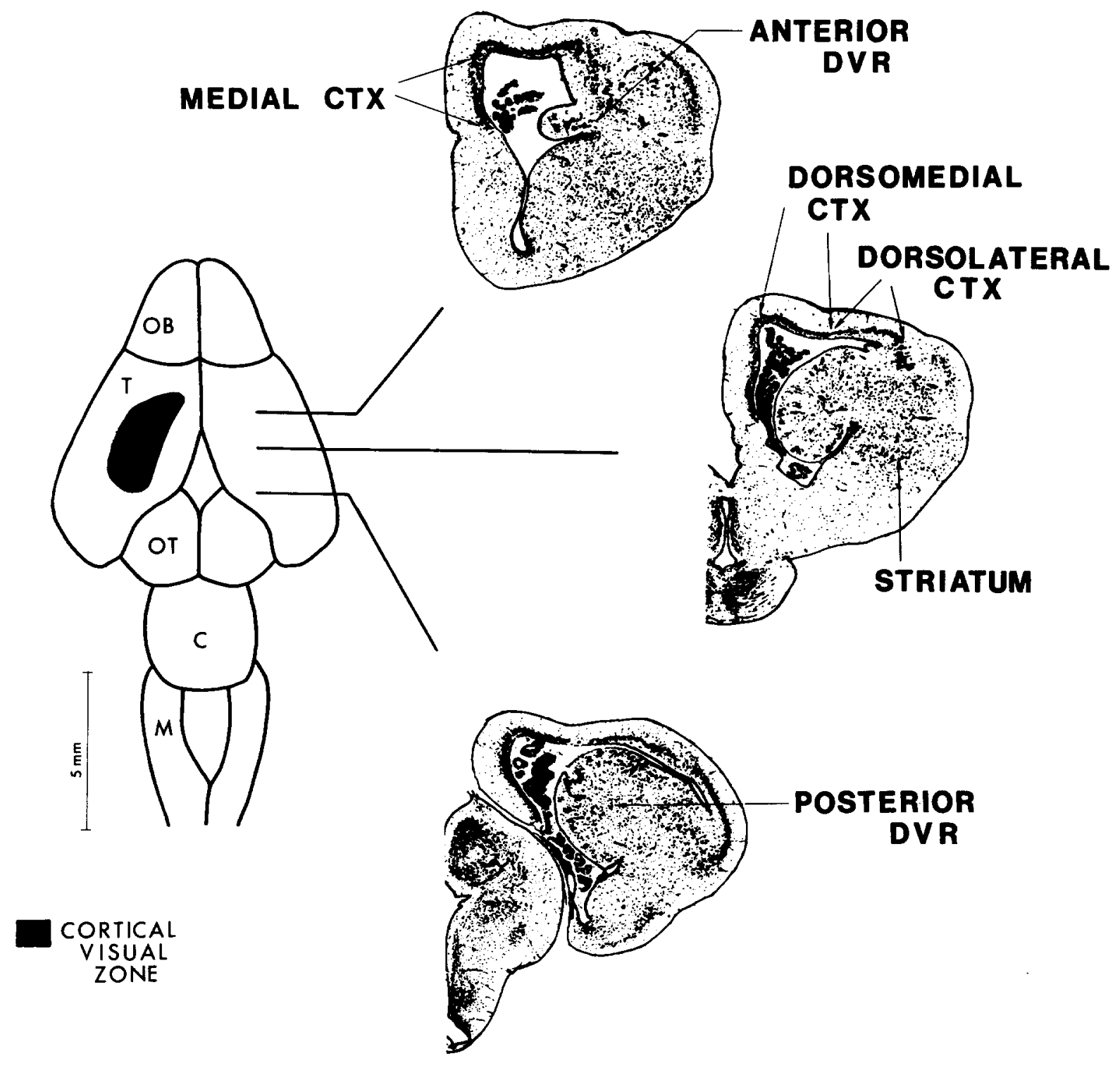

Fig. 1. A line drawing of a dorsal view of the brain of Chrysemys picta appears to the left. Representative telencephalic levels are illustrated to the right as photomicrographs of Nissl-stained transverse sections. The darkened area of the line drawing indicates the surface extent of the cortical visual zone. Abbreviations: C, cerebellum; M, medulla oblongata; OB, olfactory bulb; OT optic tectum; T, telencephalon.

44 tracks in the dorsal cortex, pallial thickening, dorsal ventricular ridge, and striatum. Most were in the dorsal cortex and the dorsal ventricular ridge and responded only to contralateral stimulation (Fig. 2). When visual units were encountered, they occurred with each stimulus presentation at the described stimulus latencies. Non-visual areas were simply those in which we found no multiple unit activity in response to visual stimulation as shown for ipsilateral stimuli in Fig. 2.
Visual multiple unit activity occurred within medial (Figs. 2, 3) lateral (Fig. 4A) divisions of the dorsal cortex, targets of the thalamofugal pathway. Along the majority of tracks, we encountered ON responses (Figs. 3, 4A), some ON/OFF responses, but no purely OFF responses (Fig. 2). Latencies of evoked responses in dorsal cortex ranged from 25 to $250 \mathrm{~ms}$. Multiple unit activity recorded at the surface of lateral and medial dorsal cortex was associated with either positive or negative evoked 


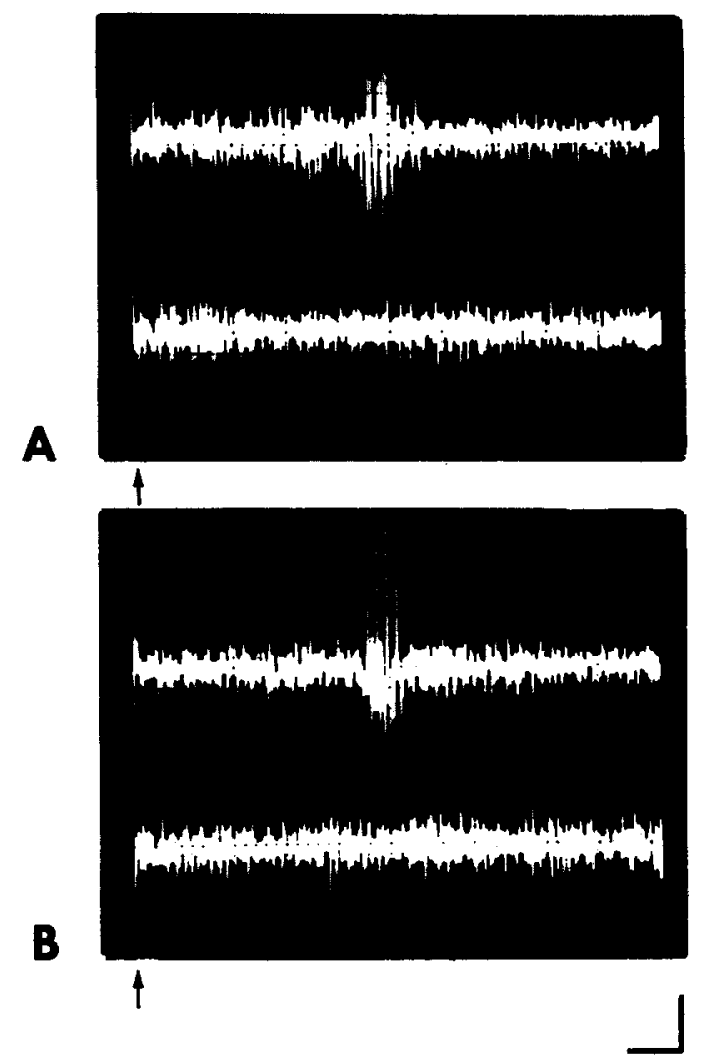

Fig. 2. Multiple unit activity (MUA) in the medial division of the dorsal cortex, elicited by onset of light stimulation. In this and Figs. 3-5, the time of onset or offset of light stimulation is indicated by an arrow below each photograph of the oscilloscope traces. In all cases, the presence or absence of light stimulation lasted the duration of the illustrated trace. A: MUA in response to light onset (flash rate $=$ once in $20 \mathrm{~s}$ ). Top trace shows contralateral MUA; bottom shows no MUA after ipsilateral stimulation. B: MUA at stimulus offset (flash rate $=$ once in $4 \mathrm{~s}$ ). Top trace shows contralateral MUA; bottom shows no MUA after ipsilateral stimulation. Recordings filtered at $0.3-1.0 \mathrm{kHz}$. Vertical scale $=10 \mathrm{mV}$; horizontal scale $=20 \mathrm{~ms}$.

potentials (monopolar recordings). Positive potentials with latencies between 110 and $250 \mathrm{~ms}$ coincided with multiple units over a $110-250 \mathrm{~ms}$ range. Negative potentials with latencies of $50-100 \mathrm{~ms}$ coincided with multiple units over a $50-100 \mathrm{~ms}$ range. Multiple units in the range of $140-250 \mathrm{~ms}$ were found only after a stimulus delay of $20 \mathrm{~s}$.

Deep cortical penetrations revealed evoked potentials associated with polarity inversions (Fig. 3). In a typical monopolar recording, evoked potential activity was negative at the surface, became biphasic with increasing depth, then became positive at the depth where multiple units appeared. The amplitude of the evoked potential typically decreased with repeated stimulation (Fig. $3 \mathrm{~A}-\mathrm{C}$ ).

In the lateral division of the dorsal cortex, deep multiple unit latencies ranged from 25 to $120 \mathrm{~ms}$ for $\mathrm{ON}$ and 35 to $150 \mathrm{~ms}$ for OFF responses. In the medial division of the dorsal cortex, multiple unit latencies for $\mathrm{ON}$ and $\mathrm{OFF}$ responses were from 25 to $250 \mathrm{~ms}$ and 20 to $40 \mathrm{~ms}$, respectively. In both divisions of dorsal cortex, a stimulus delay of $20 \mathrm{~s}$ recruited additional units at the same or longer latencies than those seen with stimulation every $4 \mathrm{~s}$ (Fig. 4A).

One electrode track revealed late units $(110 \mathrm{~ms})$ in the pallial thickening that forms the lateral edge of the dorsal cortex.

Within the dorsal ventricular ridge, ON (Figs. 4B, $5 A, B)$ and ON/OFF responses appeared in a rostrolateral zone (Fig. 4B), corresponding to the tectofugal target, and in a medial zone that has an extensive rostrocaudal extent (Fig. 5A, B). As in dorsal cortex, we encountered no purely OFF responses. In the lateral zone of the dorsal ventricular ridge, latencies for multiple units ranged from 18 to $80 \mathrm{~ms}$ for $\mathrm{ON}$ and 18 to $50 \mathrm{~ms}$ for $\mathrm{OFF}$ responses. In the medial zone of the dorsal ventricular ridge, multiple units had longer latencies, ranging from 40 to $120 \mathrm{~ms}$ for $\mathrm{ON}$ and 40 to $160 \mathrm{~ms}$ for OFF responses. Stimulus delays of $20 \mathrm{~s}$ recruited late units in both the lateral (ON, $60-80 \mathrm{~ms}$; OFF, $30-50 \mathrm{~ms}$ ) and medial (ON, 70-120 ms; OFF, 80-150 ms) zones (Fig. 5A, B).

Visually responsive units were also found in the striatum at the level of the anterior commissure (double arrows, Fig. 4A). It is possible such recordings were from fibers of passage which terminate in the dorsal ventricular ridge or dorsal cortex ${ }^{18}$. Response latencies were similar to those in the dorsal cortex, ranging from 25 to $110 \mathrm{~ms}$ for $\mathrm{ON}$, and 30 to $120 \mathrm{~ms}$ for OFF responses. Stimulus delays of $20 \mathrm{~s}$ recruited units in the same latency range as seen after stimulus delays of $4 \mathrm{~s}$.

Multiple unit activity with the shortest latencies was encountered in the lateral thalamus (ON, 12-50 $\mathrm{ms}$; OFF, $10-35 \mathrm{~ms}$ ) and the optic tectum (ON, $12-40 \mathrm{~ms}$; OFF, 9-12 ms), regions of primary retinal input ${ }^{6}$. 
A
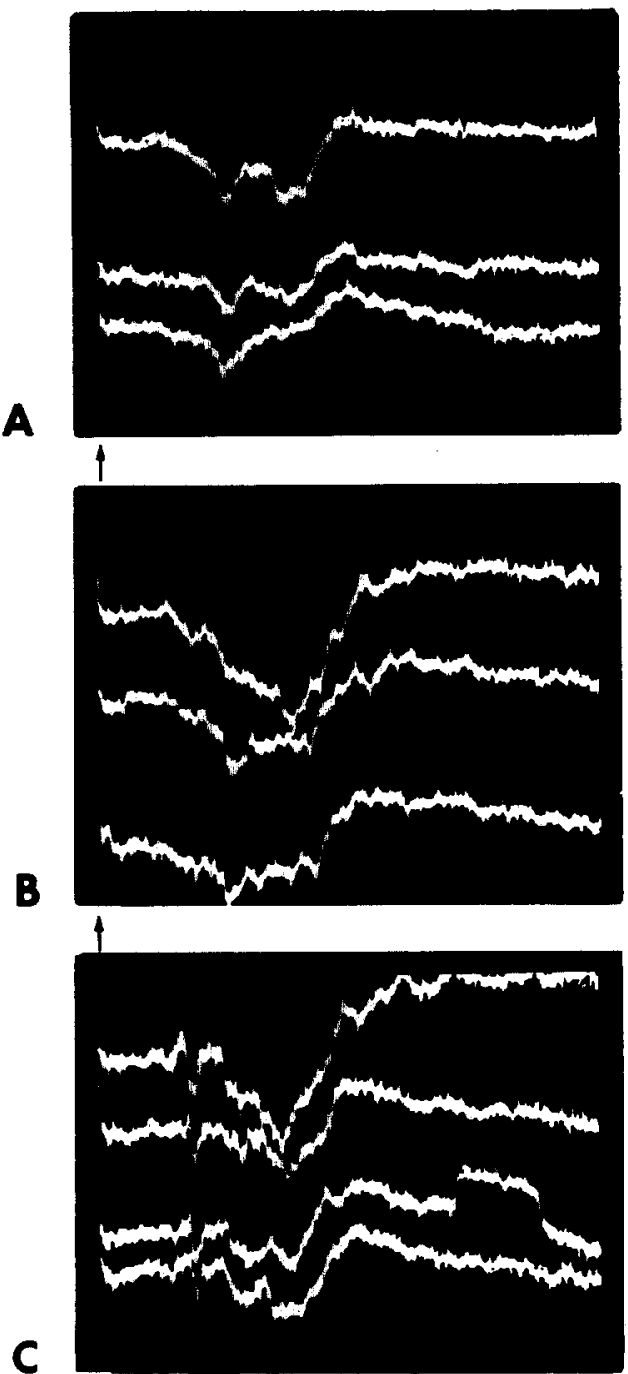

C

1

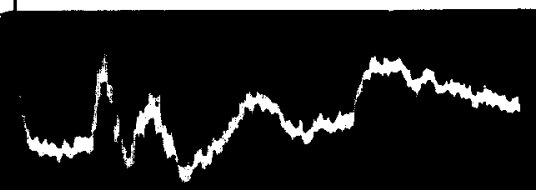

D

$$
1
$$
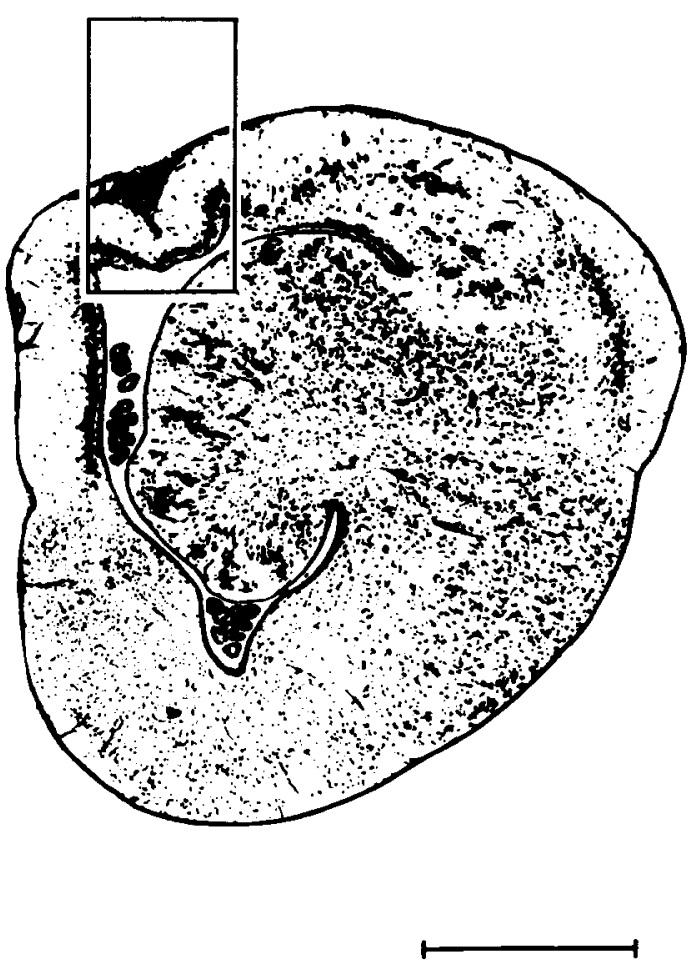

Fig. 3. Evoked potential activity elicited by onset of contralateral stimulation at 4 successive depths in the medial division of the dorsal cortex. Positive is above the baseline of each trace; negative is below the baseline. In this and Figs. 4 and 5 , oscilloscope traces appear to the left; photomicrographs of transverse sections of Nissl-stained material appear to the right and illustrate the recording sites (enclosed areas). Bar scale for this and Figs. 4 and $5=1 \mathrm{~mm}$. A-C: stimulus was withheld for $20 \mathrm{~s}$ (trace 1), then delivered once every $4 \mathrm{~s}$ (traces 2, 3, and 4). D: stimulation was witheld for $20 \mathrm{~s}$ in both traces. For the lower trace, low frequency components were filtered out at $0.3-3.0 \mathrm{kHz}$ to show MUA. Vertical scale (A-C) $=20 \mathrm{mV}$; vertical scale (D) $=10 \mathrm{mV}$; horizontal scale $(\mathrm{A}-\mathrm{D})=20 \mathrm{~ms}$. 

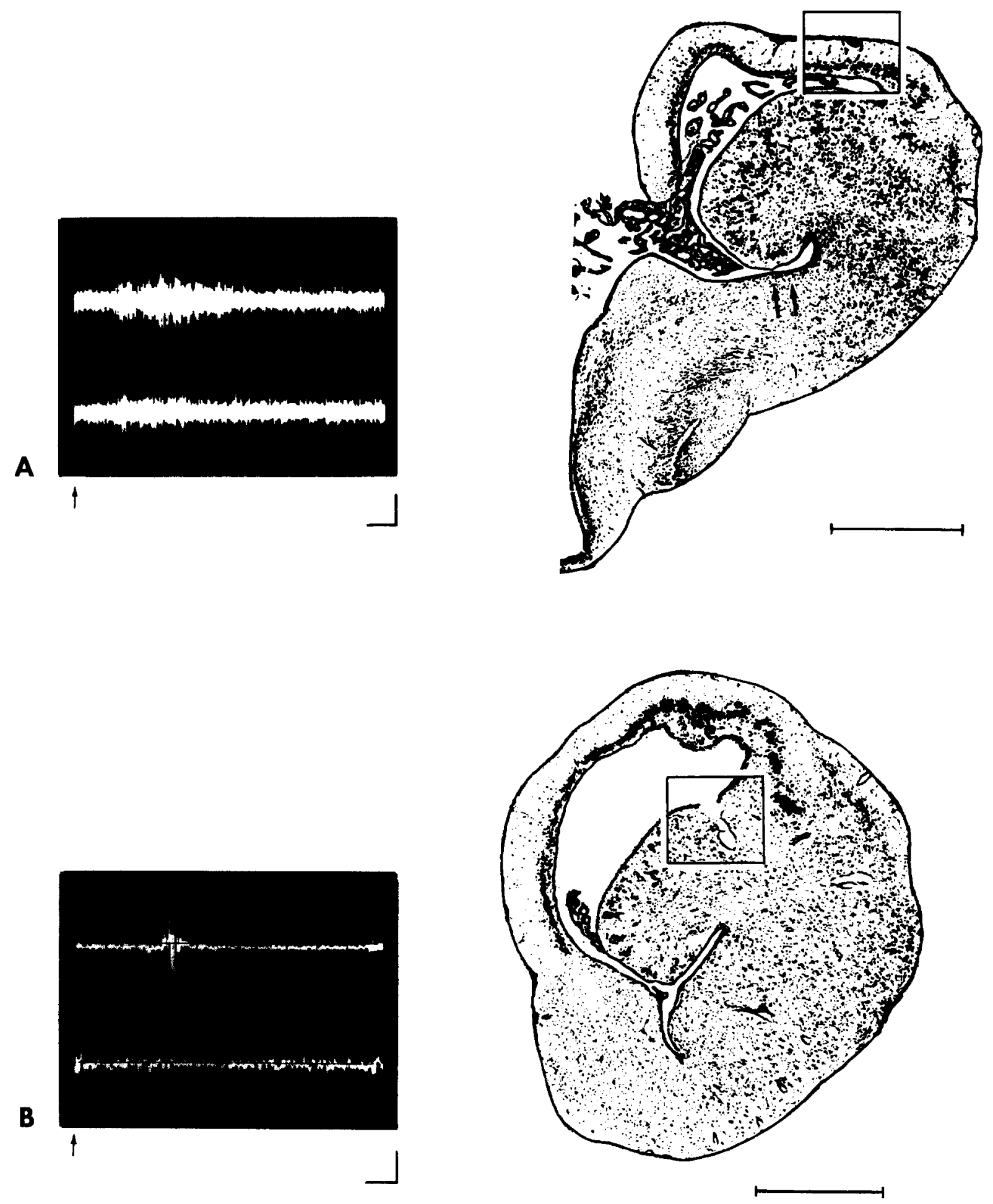

Fig. 4. A: MUA in the lateral division of dorsal cortex after onset of light stimulus. Top trace shows MUA elicited after $20 \mathrm{~s}$ stimulus delay; bottom trace is MUA after $4 \mathrm{~s}$ delay. An electrolytic lesion marks the recording track. Traces filtered at 0.3-3.0 $\mathrm{kHz}$. Vertical scale $=5 \mathrm{mV}$; horizontal scale $=20 \mathrm{~ms}$. B: MUA in the lateral dorsal ventricular ridge after a $4 \mathrm{~s} \mathrm{stimulus} \mathrm{delay} \mathrm{(top}$ trace), and after an electrolytic lesion (bottom trace and photomicrograph). Traces filtered at $0.1-1.0 \mathrm{kHz}$. Arrows indicate the positions of visually responsive tracks in the striatum. Vertical scale $=10 \mathrm{mV}$; horizontal scale $=20 \mathrm{~ms}$. 


\section{DISCUSSION}

\section{Previous studies}

Telencephalic visual responses found in the dorsal cortex, the dorsal ventricular ridge, and the striatum of turtles confirm several previous anatomical and physiological reports ${ }^{3,4,13,16,18,26,34,35}$. Visual units have been reported for hippocampal cortex ${ }^{35}$, and it is likely that this area corresponds to portions of our dorsal cortex (Fig. 2B, ref. 7). Anatomical comparisons with earlier physiological studies are difficult, as the authors did not histologically confirm the positions of their recording sites.

There are several similarities between our findings in the painted turtle, Chrysemys picta, and those reported for the box turtle, Emys orbicularis: (a) comparable location and limits of a surface map of the visual zone (Fig. 1) in dorsal cortex ${ }^{26,33}$; (b) both $\mathrm{ON}$ and $\mathrm{OFF}$ responses in all telencephalic visual zones $^{13}$, (c) a decrement in amplitude of the evoked response with repeated stimulation ${ }^{26}$.

A recent single unit study of the anterior dorsal ventricular ridge in Pseudemys (recording sites were not illustrated) reports visual units with large receptive fields, a preference for large stimuli and motion but not directional sensitivity ${ }^{9}$. As the authors pointed out, such properties suggest a large degree of spatial convergence in the ascending visual pathway to the dorsal ventricular ridge.

We did not find binocular units in Chrysemys, as reported in Emys ${ }^{13}$. Although this may represent a real species difference, it is more likely due to our use of stationary stimuli, as moving stimuli were used for Emys.

We identify two visual zones in the dorsal ventricular ridge. The lateral zone corresponds topographically to the target of the tectofugal pathway $^{3,4,18}$, while the medial zone overlaps targets of ascending auditory and somatosensory pathways ${ }^{3}$. Hall and Ebner ${ }^{18}$ also reported thalamic input to a rostral sector of the medial zone, which indicates that medial visual units may also arise from direct thalamofugal inputs. Additional studies may indicate multimodal convergence on single units in the medial ridge, as shown for visual units of the dorsal cortex ${ }^{7}$. Should additional studies reveal multimodal convergence in the lateral ridge (tectofugal target), the data would suggest that turtles are not characterized by a pallial zone concerned solely with vision. Although several studies document ascending auditory, somesthetic and visual inputs to separate portions of the dorsal ventricular ridge ${ }^{3,15}$, 17, we have no data on its intrinsic connections, Such pathways may provide the basis for multimodal convergence throughout the dorsal ventricular ridge.

\section{Phylogenetic comparisons}

Thalamofugal pathway. In lizards, electrophysiological data identified the medial cortex as the major cortical visual zone, although the anatomical basis for this input is still unknown ${ }^{2,14}$. In contrast to turtles, no retinothalamo-dorsal cortical pathway was reported for lizards and snakes, where a retinothalamic pathway was believed to terminate in the lateraldorsalventricularridge ${ }^{25,39}$. However, a recent study in lizards reports a retinothalamic pathway ${ }^{10}$ terminating in the pallial thickening that forms the lateral edge of the lateral dorsal cortex, the latter possibly having been misidentified by earlier investigators as a portion of the dorsal ventricular ridge ${ }^{12}$. Thus, contrary to previous beliefs, both turtles and lizards (and possibly snakes) may share the common feature of a retinothalamo-cortical pathway.

In birds, a retinothalamic pathway terminates in a dorsal telencephalic structure - the lateral Wulst ${ }^{19,22,27-29}$. Although retinal efferents are completely crossed (unlike those in lizards, snakes, and turtles ${ }^{6,31,32}$ ) the thalamofugal pathway has ipsilateral, contralateral, and bilateral components ${ }^{22,28,36}$. This contrasts with reptiles where retinal efferents are bilateral ${ }^{6}$ and visual thalamofugal pathways are ipsilateral ${ }^{9,18,39}$. Together, the data suggest that birds independently lost ipsilateral retinothalamic projections, but developed bilateral visual thalamotelencephalic pathways.

Tectofugal pathway. As in turtles, a tectofugal visual pathway terminates in the lateral dorsal ventricular ridge and striatum of lizards ${ }^{11}$. However, there are no detailed data on the extent of subcortical visual areas.

An avian tectofugal pathway also terminates in the paleostriatum and in the ectostriatum, a division of the dorsal ventricular ridge 21,37 . As in turtles, more than one visual zone is identified in the dorsal 

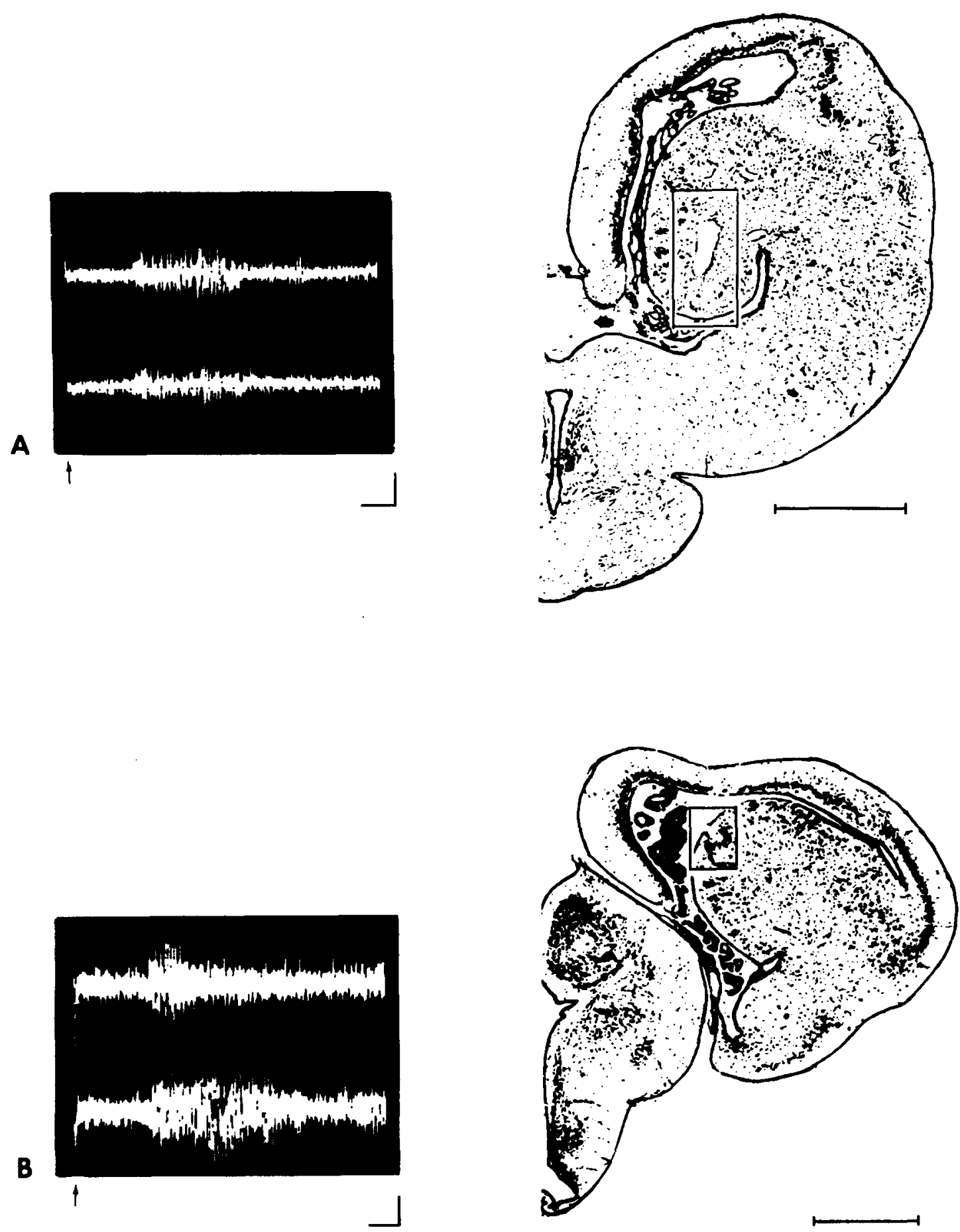

Fig. 5. A: MUA in the medial zone of the dorsal ventricular ridge after onset of light stimulus, after delays of $20 \mathrm{~s}$ (top trace) and $4 \mathrm{~s}$ (bottom trace). An electrolytic lesion marks the recording track. Traces filtered at $0.3-1.0 \mathrm{kHz}$. Vertical scale $=10 \mathrm{mV}$; horizontal scale $=20 \mathrm{~ms}$. B: MUA in the caudomedial ridge after stimulus delays of $4 \mathrm{~s}$ (top trace) and $20 \mathrm{~s}$ (bottom trace). Tissue disruption indicates the recording track. Traces filtered at $0.3-1.0 \mathrm{kHz}$. Arrows indicate visually responsive units. Vertical scale $=5 \mathrm{mV}$; horizontal scale $=20 \mathrm{~ms}$. 
ventricular ridge of pigeons, where a visual circuit connects ectostriatum to an ectostriatal belt which, in turn, relays to lateral neostriatum ${ }^{38}$. Analogous interridge pathways in turtles may account for visual input to the medial ridge (unpublished observations), which receives input from the lateral ridge a tectofugal target.

In summary, the present analysis reveals at least 3 visual zones in the pallium of turtles - dorsal cortex, lateral dorsal ventricular ridge, and medial dorsal ventricular ridge. The data indicate that

\section{REFERENCES}

1 Andry, M. L., Investigations of CNS Plasticity in Garter Snakes, Ph. D. Thesis, University of Colorado, Boulder, Colorado, 1975.

2 Andry, M. L. and Northcutt, R. G., Telencephalic visual responses in the lizard Gekko gecko, Soc. Neurosci. Abstr., 2 (1976) 176.

3 Balaban, C. D. and Ulinski, P. S., Organization of thalamic afferents to anterior dorsal ventricular ridge in turtles. I. Projections of thalamic nuclei, J. comp. Neurol., 200 (1981) 95-129.

4 Balaban, C. D. and Ulinski, P. S., Organization of thalamic afferents to anterior dorsal ventricular ridge in turtles. II. Properties of the rotundo-ridge map, J. comp. Neurol., 200 (1981) 131-150.

5 Bass, A. H., Andry, M. L. and Northcutt, R. G., Telencephalic visual responses in the painted turtle, Chrysemys picta, Soc. Neurosci. Abstr., 3 (1977) 89.

6 Bass, A. H. and Northcutt, R. G., Retinal recipient nuclei in the painted turtle, Chrysemys picta: an autoradiographic and HRP study, J. comp. Neurol., 199 (1981) 97-122.

7 Belekhova, M. G., Neurophysiology of the Forebrain. In C. Gans, R. G. Northcutt, and P. Ulinski (Eds.), Biology of the Reptilia, Vol. 10, Academic Press, London, 1979, pp. 297-359.

8 Benowitz, L. I., Functional Organization of the Avian Telencephalon. In S. O. E. Ebbesson (Ed.), Comparative Neurology of the Telencephalon, Plenum Press, New York, 1980, pp. 389-421.

9 Bruce, L. and Butler, A. B., Thalamocortical organization in two lizards, Soc. Neurosci. Abstr., 7 (1981) 85.

10 Butter, A. B. and Northcutt, R. G., New thalamic visual nuclei in lizards, Brain Res., 149 (1978) 469-476.

11 Distel, H. and Ebbesson, S. O. E., Connections of the thalamus in the monitor lizard, Soc. Neurosci. Abstr., 1 (1975) 559.

12 Dünser, K., Maxwell, J. and Granda, A. M., Visual properties of cells in anterior dorsal ventricular ridge of turtle, Neurosci. Lett., 25 (1981) 281-285.

13 Gudel'nikov, V. I., Morenkov, E. D. and Pivovarov, A. S., Unit responses of the turtle forebrain to visual stimuli, Neurosci. Behav. Physiol., 5 (1972) 235-242 (translation). turtles, like birds and mammals ${ }^{20}$, possess multiple visual pallial zones.

\section{ACKNOWLEDGEMENTS}

The authors wish to thank Drs. D. A. Bodznick, T. H. Bullock, C. D. Hopkins and R. E. Phillips and two anonymous referees for many helpful suggestions on the manuscript, and Diane Johnson for typing assistance. This work was supported by NIH grants to R.G.N., M.L.A., and A.H.B. and funds from the Division of Biological Sciences, University of Michigan, to A.H.B.

14 Gusel'nikov, V. I. and Supin, A. Y., Visual and auditory regions in hemispheres of lizard forebrain, Trans. Suppl. Fed. Amer. Soc. Exp. Biol., 23 (1964) 641-646.

15 Hall, W. C., Visual pathways to the telencephalon in reptiles and mammals, Brain Behav. Evol., 5 (1972) 95-113.

16 Hall, J. A., Foster, R. E., Ebner, F. F. and Hall, W. C., Visual cortex in a reptile, the turtle (Pseudemys scripta and Chrysemys picta), Brain Behav. Evol., 130 (1977) 197-216.

17 Hall, W. C. and Ebner, F. F., Parallels in the visual afferent projections of the thalamus in the hedgehog (Paraechinus hypomelas) and the turtle (Pseudemys scripta), Brain Behav. Evol., 3 (1970) 135-153.

18 Hall, W. C. and Ebner, F. F., Thalamotelencephalic projections in the turtle (Pseudemys scripta), J. comp. Neurol., 140 (1970) 101-122.

19 Hunt, S. P. and Webster, K. E., Thalamo-hyperstriate interrelations in the pigeon, Brain Res., 44 (1972) 647-651.

20 Kaas, J., A comparative survey of visual cortex organization in mammals. In S. O. E. Ebbesson (Ed.), Comparative Neurology of the Telencephalon, Plenum Press, New York, 1980, pp. 483-502.

21 Karten, H. J. and Hodos, W., Telencephalic projections of the nucleus rotundus in the pigeon (Columba livia), $J$. comp. Neurol., 140 (1970) 35-52.

22 Karten, H. J., Hodos, W., Nauta, W. J. H. and Revzin, A. M., Neural connections of the 'visual wulst' of the avian telencephalon. Experimental studies in the pigeon (Columba livia) and the owl (Speotyto cunicularis), J. comp. Neurol., 150 (1973) 253-277.

23 Karten, H. J. and Revzin, A. M., The afferent connections of the nucleus rotundus in the pigeon, Brain Res., 2 (1966) 368-377.

24 Kosareva, A. A., Projection of optic fibers to visual centers in a turtle (Emys orbicularis), J. comp. Neurol., 130 (1967) 263-275.

25 Lohman, A. H. M. and van Woerden-Verkley, I., Ascending connections to the forebrain in the tegu lizard, J. comp. Neurol., 182 (1978) 555-594.

26 Mazurskaya, P. Z., Retinal projections in the forebrain of Emys orbicularis, Neurosci. Behav. Physiol., 6 (1971) 75-82 (translation).

27 Meier, R. E., Mihailovic, J. and Cuénod, M., Thalamic organization of the retino-thalamo-hyperstriatal pathway in the pigeon (Columba livia), Exp. Brain Res., 19 (1974) 351-364. 
28 Miceli, D., Peyrichoux, J. and Repérant, J., The retinothalamo-hyperstriatal pathway in the pigeon (Columba livia), Brain Res., 100 (1975) 125-131.

29 Mihailovic, J., Peristic, M., Bergonzi, R. and Meier, R. E., The dorso-lateral thalamus as a relay in the retinowulst pathway in pigeon (Columba livia), Exp. Brain Res., 21 (1974) 229-240.

30 Northcutt, R. G., Evolution of the telencephalon in nonmammals, Ann. Rev. Neurosci., 4 (1981) 301-350.

31 Northcutt, R. G. and Butler, A. B., Evolution of reptilian visual systems: retinal projections in a nocturnal lizard, Gekko gecko (Linnaeus), J. comp. Neurol., 157 (1974) 453-466.

32 Northcutt, R. G. and Butler, A. B., Retinal projections in the Northern water snake, Natrix sipedon sipedon (L.), J. Morph., 142 (1974) 117-136.

33 Orrego, F., The reptilian forebrain, I. The olfactory pathways and cortical areas in the turtle, Arch. Ital. Biol., 99 (1961) 425-445.

34 Parent, A., Striatal afferent connections in the turtle
(Chrysemys picta) as revealed by retrograde axonal transport of horseradish peroxidase, Brain Res., 108 (1976) 25-36.

35 Pivovarov, A. S. and Trepakov, V. V., Intracellular analysis of unit responses to afferent stimulation in the general and hippocampal cortex of turtles, Neurosci. Behav. Physiol., 3 (1972) 235-242 (translation).

36 Repérant, J., Nouvelles donnees sur les projections visuelles chez le pigeon (Columba livia), J. Hirnforsch., 14 (1973) 151-187.

37 Revzin, A. M. and Karten, H. J., Rostral projections of the optic tectum and the nucleus rotundus in the pigeon, Brain Res., 3 (1966) 264-276.

38 Ritchie, T. C. and Cohen, D. H., The avian tectofugal pathway: projections of its telencephalic target, the ectostriatal complex, Soc. Neurosci. Abstr., 3 (1977) 94.

39 Wang, R. T. and Halpern, M., Afferent and efferent connections of thalamic nuclei of the visual system of garter snakes, Anat. Rec., 187 (1977) 741-742. 